University of Rhode Island

DigitalCommons@URI

The Rhode Island Current Conditions Index

Economics

7-2018

\title{
Rhode Island Current Conditions Index - July 2018
}

Leonard Lardaro

University of Rhode Island, lardaro@uri.edu

Follow this and additional works at: https://digitalcommons.uri.edu/ricci

Part of the Econometrics Commons

Terms of Use

All rights reserved under copyright.

\section{Recommended Citation}

Lardaro, Leonard, "Rhode Island Current Conditions Index -- July 2018" (2018). The Rhode Island Current Conditions Index. Paper 175.

https://digitalcommons.uri.edu/ricci/175

This Newsletter is brought to you for free and open access by the Economics at DigitalCommons@URI. It has been accepted for inclusion in The Rhode Island Current Conditions Index by an authorized administrator of DigitalCommons@URI.For more information, please contact digitalcommons-group@uri.edu. 


\title{
CURRENT CONDITIONS
}

\section{LEONARD LARDARO, URI}

\author{
Available Online: http: / / www.Ilardaro.com/current.htm \\ Twitter: @ladardo
}

VOL XXV

NUMBER 8

JUL 2018

The third quarter didn't exactly start off with a bang for Rhode Island. While its 2018 economic performance overall has been both hopeful and at times disappointing, things got a bit more dicey in July.

The July Current Conditions Index fell all the way from 83 in June (when ten of twelve indicators improved) to 58, barely above neutral, as only seven indicators showed improvement relative to last July. Not only was the July value the lowest this year, July marked the fifth time this year the CCI has failed to exceed its year-earlier value. What I find perplexing is that the July 2017 CCI wasn't exactly stellar - at 75 it should not have been that difficult to improve upon.

Let's not get too carried away. Remember the first rule of analyzing any economy: Never place too much weight on values for a single month. That guidance provides a meaningful context (or more realistically cover) with which to undertake this analysis. First and foremost, we must remember that Rhode Island's economy is continuing to perform at its best levels since the Great Recession. Perhaps the greatest positive for July pertains to what I have referred to as the "left behind" indicators-these

\begin{tabular}{|l|r|r|}
\hline \multicolumn{3}{|c|}{ CCI Indicators - \% Change } \\
\hline Government Employment & 0.0 & \\
\hline US Consumer Sentiment & 4.9 & Y \\
\hline Single-Unit Permits & -18.3 & \\
\hline Retail Sales & 3.7 & Y \\
\hline Employment Services Jobs & -0.0 & \\
\hline Priv. Serv-Prod Employment & 2.9 & Y \\
\hline Total Manufacturing Hours & 5.2 & Y \\
\hline Manufacturing Wage & -0.6 & \\
\hline Labor Force & 1.3 & Y \\
\hline Benefit Exhaustions & -11.5 & Y \\
\hline New Claims & 16.0 & \\
\hline Unemployment Rate (change) & -0.3 & Y \\
\hline \multicolumn{2}{|c|}{ Y = Improved Value } \\
\hline
\end{tabular}

continued to gain further ground in July, likely a continuation of the LO portion of FILO (First In, Last Out of national economic weakness). So levels overall are indeed getting better. The Current Conditions Index is a momentum index, reflecting how much levels are changing. So, if the July CCI results hold after possible revisions, and more disappointing values follow, an outcome not certain by any means, that would reflect that Rhode Island's rate of growth is beginning to move toward a peak. Not the end of the world, but something we can't entirely dismiss, since with our FILO status, our economy peaks anywhere from twelve to eighteen months before the national economy.

For July, only seven CCI indicators improved. All did so in spite of difficult comps a year ago. As has been true throughout 2018, the "left behind" indicators continued to improve, sustaining uptrends that began in January. The labor force participation rate, the percentage of our resident population in the labor force, rose to its highest level since March of 2016: 64.9 percent. The employment rate, the percentage of the resident population that is employed, attained its highest value since late 2008: 62.2 percent. While both remain well below their prior cyclical highs (see table below), their July and 2018 performances overall are encouraging. This is significant since payroll employment (the number of jobs in RI) has already surpassed its prior peak, and now resident employment (the number of employed RI residents) is moving ever closer to its prior peak.

Only two of the five leading indicators contained in the $\mathrm{CCI}$ improved this month. New Claims rose in July $(+16.0 \%)$ postponing its ability to resume a downtrend. Rhode Island's goods-producing sector's performance was mixed. Total Manufacturing Hours, a proxy for manufacturing output, an important element of Rhode Island's strength over the past two years, rose strongly in July $(+5.2 \%)$ based improvements in both employment and the length of the workweek. Single-Unit Permits, which reflect new home construction, decreased again at a double-digit rate $(-18.3 \%)$, its sixth decline in the past nine months. Employment Service Jobs, a leading labor market indicator that includes temporary employment, failed to improve in July, perhaps signaled by its recent slowing growth rates. US Consumer Sentiment increased in July $(+4.9 \%)$, its sixth consecutive improvement. Retail Sales grew again $(+3.7 \%)$, but growth remained below recent double-digit rates. Government Employment remained unchanged from its level a year ago. Private Service-Producing Employment growth remained above the one percent level, accelerating in July (+2.9\%). Finally, Benefit Exhaustions, the most timely measure of longer-term unemployment, fell sharply in July $(-11.5 \%)$.

Finally, more great news for the mindless economy watchers, those for whom the Unemployment Rate tells all: The Unemployment Rate improved again in July, allaying their fears of the imminent collapse of Western Civilization. Better yet, this was again accompanied by both monthly and annual rises in our Labor Force, its thirteenth consecutive year-over-year increase.

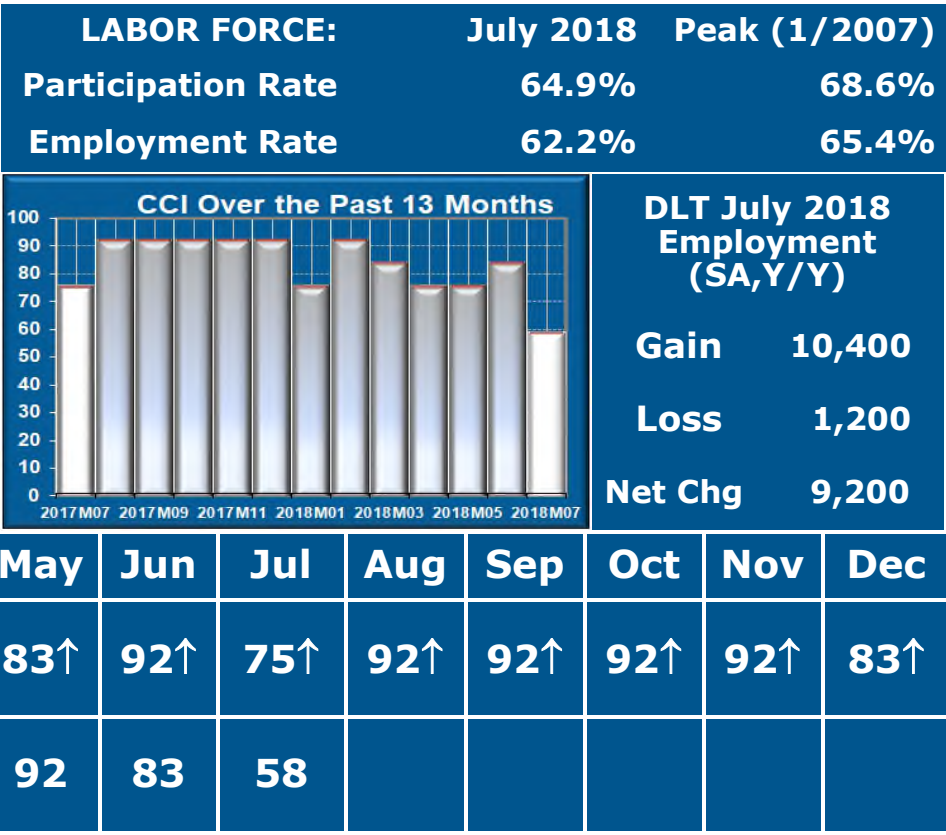

Copyright $\odot$ 2017, 2018 Leonard Lardaro, Ph.D. All rights reserved. 